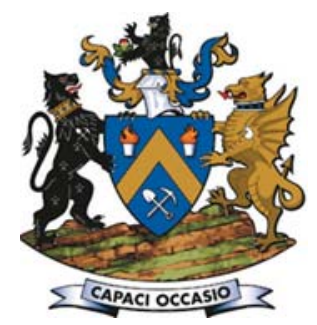

\title{
Influence of additives on the devolatilization product yield of typical South African coals, and effect on tar composition
}

\author{
by N.C. Bean*, J.R. Bunt ${ }^{\dagger}$, C.A. Strydom ${ }^{\ddagger}$, H.W.J.P. Neomagus ${ }^{\dagger}$, \\ D. van Niekerk*, and B.B. Hattinghs
}

\section{Synopsis}

South African coal is mainly used for electricity generation by means of pulverized fuel combustion and liquid fuels production via indirect gasification technology and Fischer-Tropsch synthesis. In order to expand the utilization potential with regard to the production of high-value compounds, the effect of in situ organic/inorganic salts on the devolatilization behaviour and product spectrum of tars derived from three typical South African coals was investigated. Potassium-based salts and alumina were chosen as additives, based on numerous literature citations stating that these were successful in catalysing coal char devolatilization reactions and influencing tar quantity and quality. Using a modified Fischer Assay analysis experimental method, the solid and liquid product yields were determined at a temperature of $520^{\circ} \mathrm{C}$. An increase in additive loading decreased the yield of liquid products by up to $50 \%$, while the char yield increased by up to $10 \%$. The quality of the liquid products formed was also affected by an increase in additive load, with the resultant tars having a lighter average molecular weight and a lower average boiling point, indicating significant changes in the product composition. Due to the potential for the production of high-value chemicals from coal, a study of this nature represents a significant insight into the devolatilization behaviour of typical South African coal, and could serve as a precursor for the development of a technology capable of producing high-value chemicals as well as a coal-derived char suitably catalysed for gasification to produce synthesis gas.

Keywords

coal, char reactivity, devolatilization, tar, mineral additives.

\section{Introduction}

In this study, three coal samples from the Witbank area of South Africa were specifically chosen with a range of maceral content. Previous studies investigating the effect of inorganic additives on devolatilization have found that several additives affect the amount of volatiles derived from the studied coal (Liu et al., 2004; Ahmad et al., 2009; Wu, Sugimoto, and Kawashima, 2003). Studies investigating the effect of operational conditions (temperature, pressure, and heating rate) on the devolatilization product composition have found that changing these conditions will also influence the product yield and composition (Juntgen and van Heeck, 1977; Rennhack, 1964; Peters and Bertling, 1965). The importance of studying coals from South Africa becomes apparent when comparing coals from this region to coals that are mined in other regions. Coals from North America are spread between anthracite, bituminous, sub-bituminous, and lignite ranks (vitrinite-rich); this wide variety of rank is also the case with many of the world's other top producers of coal, as reported by the World Coal Institute (2008). As a result, most previous studies (especially those done outside of South Africa) are not applicable to the highinertinite, high-ash bituminous coals from this region. Previous studies performed in South Africa were not focused on the devolatilization products, but investigated the process of devolatilization with regard to South African coals (Beukman, 2009). Due to the potential for the production of high-value chemicals from coal, it is deemed appropriate to investigate the effect of extraneous additives on the quantity and composition of the tars that can be derived from South African coal when pyrolised at a slow heating rate in the presence of an alkali metal catalyst. Should the tar yield be reduced due to additive addition, and lighter products be formed, then this could be seen as a positive step toward the production of valuable chemicals from coal.

\section{Literature review and theory}

When coal is heated in an inert atmosphere (absence of oxygen), water vaporization and devolatilization takes place (Bell, Towler, and Fan, 2011). This is the initial step in any coal conversion process, where up to $70 \%$ of the initial coal weight can be lost (Solomon and

* Sasol Technology (Pty) Ltd, Sasolburg, South Africa.

+ Coal Research Group, School of Chemical and Minerals Engineering, North-West University, Potchefstroom Campus, Potchefstroom, South Africa.

* Chemical Resource Beneficiation (CRB), NorthWest University, Potchefstroom, South Africa.

\& Sasol Chemical Industries (Pty) Ltd, Sasolburg, South Africa.

(C) The Southern African Institute of Mining and Metallurgy, 2018. ISSN 2225-6253. Paper received Feb. 2017; revised paper received Mar. 2017. 


\section{Influence of additives on the devolatilization product yield of typical South African coals}

Hamblen, 1985). At temperatures lower than $350^{\circ} \mathrm{C}$, mostly vaporization takes place (Ladner, 1988). When coal reaches temperatures above $320^{\circ} \mathrm{C}$, bonds between carbon and oxygen, nitrogen, and sulphur break and fragmentation occurs. This process is called pyrolysis. The four main products formed during pyrolysis are water vapour, gas, char, and tar (Fuchs and Sandhoff, 1942; Solomon and Hamblen, 1985). Fragments are created by the breaking of labile bonds between aromatic clusters (Shadle, Berry, and Syamlal, 2002). These fragments are unstable, but pyrolyse further to stable compounds (Ahmad et al., 2009; Bell, Towler, and Fan, 2011; Liu et al., 2004). Low molecular-weight components vaporize and escape the coal particles in the form of tar and gas. The high molecular-weight components do not vaporize and re-attach to the coal lattice (Fletcher et al., 1992). All the components with a molecular weight higher than $\mathrm{C}_{6}$ are defined as tars, whereas those lighter than $\mathrm{C}_{6}$ (of which $\mathrm{CO}, \mathrm{CO}_{2}, \mathrm{CH}_{4}, \mathrm{C}_{2} \mathrm{H}_{6}$, and $\mathrm{H}_{2} \mathrm{O}$ are the most significant) are defined as the gas. Both tar and gas are in the vapour phase during pyrolysis (Chen and Wen, 1979).

Primary and secondary devolatilzsation reactions occur when devolatilizing at high temperatures (Ladner, 1988). During primary devolatilization the weak bridges break to form the fragments, as discussed above. Further consumption of hydrogen from hydroaromatic or aliphatic functionalities will increase the hydrogen content in the aromatics. Alkyl aromatics, alkyl radicals, and aromatic ring structures are subsequently formed due to the breakage of hydrocarbon linkages (Wanzl, 1988). These molecules have a low molecular weight and vaporize to light oils and low molecular-weight tars (Smith et al., 1994). It has been found that secondary tar reactions during pyrolysis result in the formation of polycyclic aromatic hydrocarbons (PAH) (Nelson et al., 1988; Smith et al., 1994). The aromaticity of the formed tar is greatly affected by the amount of mono- and polyaromatic units, which are formed by phenols and aliphatic molecules present in the tar. $C_{3}$ and $C_{4}$ olefins undergo Diels-Alder cyclization reactions to form cycloolefins (Cypres and Soudan-Moinet, 1980). Further reactions during secondary stages cause the formation of $\mathrm{CH}_{4}$ (from methyl groups), $\mathrm{HCN}$ (from nitrogen species), $\mathrm{CO}$ (from ethers), and $\mathrm{H}_{2}$ (ring structure condensation reactions) (Kristiansen, 1996).

As discussed earlier, devolatilization behaviour has been shown to be most affected by the operating temperature $\mathrm{Hu}$ et al., 2004), where an increase in operating temperature will result in an increase in volatile yield; but a large range of product compositions can be present (Hu et al., 2004; Kandiyoti, Herod, and Bartle, 2006; Kristiansen, 1996; Ladner, 1988). The reactivity of the chars formed during the pyrolysis step has been found to decrease with an increase in final pyrolysis temperature (Haykiri-Acma, Yaman, and Kucukayrak, 2012). For slow heating rates of $5-10^{\circ} \mathrm{C} / \mathrm{min}$, certain maximum tar and liquor values are observed in a range of $525-575^{\circ} \mathrm{C}$ (Öztas and Yürüm, 2000; Yaw et al., 1980). Temperatures above this range result in a decrease in tar and liquor yield, while gaseous species formation starts to be favoured more (Speight, 1994). This phenomena, and the influence on the quality and quantity of products, is discussed in a review study by Ladner (1988), comparing high-temperature $\left(900-1000^{\circ} \mathrm{C}\right)$ and low-temperature (400- $750^{\circ} \mathrm{C}$ ) pyrolysis. Liquor, light oils, and tar yields were found to be lower for the high-temperature pyrolysis, whereas gas and char yields were higher. The compositional differences can be seen in Table I. At temperatures above $800^{\circ} \mathrm{C}$, the most predominant tars formed are $\mathrm{PAH}$ with up to five rings (Nelson et al., 1988). This can also be seen in Table I by the higher aromatic/phenol ratio observed at high-temperature pyrolysis. From Table I it can further be seen that the lower molecular-weight species are formed during hightemperature pyrolysis and can be attributed to the secondary gas-phase degradation reactions taking place at higher temperatures. The tar is also more aromatic in nature, with unsubstituted PAH present at the higher pyrolysis temperatures (Nelson et al., 1988).

Gaseous biomass or coal-derived tars, for example, can react under inert conditions (thermal cracking) or with components in the producer gas such as $\mathrm{H}_{2}, \mathrm{H}_{2} \mathrm{O}$, or $\mathrm{CO}_{2}$ (gasification). The reaction rate of thermal cracking is such that temperatures of approximately $1200^{\circ} \mathrm{C}$ or higher (also depending on residence time) are needed to create a producer gas with low tar concentrations. The rate of thermal cracking of tars depends on the kind of tar. The rate decreases in the series: biomass pyrolysis oils/tars > phenolic tar compounds (phenol, cresol, naphthol) > pyrolysis tars from coal > polycyclic aromatic tar compounds (anthracene, phenanthrene, naphthalene, benzene). The rate of thermal cracking also depends on the atmosphere in which the tars are cracked because the gas phase components $\mathrm{H}_{2}, \mathrm{H}_{2} \mathrm{O}$, and $\mathrm{CO}_{2}$ play a role in the cracking reactions. $\mathrm{H}_{2} \mathrm{O}$ and/or $\mathrm{CO}_{2}$ increase the decomposition rate of tars, whereas $\mathrm{H}_{2}$ decreases the rate. The aromatic rings of tars can also be hydrogenated, which occurs only under hydrogasification conditions at high partial pressures of $\mathrm{H}_{2}$. This leads to the production of $\mathrm{CH}_{4}$.

\section{Table I \\ Quality of pyrolysis products (Adapted from Ladner, 1988)}

\begin{tabular}{|c|c|c|c|c|c|}
\hline Gas & wt \% & Light oil & wt \% & Tar & wt \% \\
\hline $\begin{array}{l}\mathrm{H}_{2} \\
\text { Hydrocarbons } \\
\mathrm{CO} \\
\mathrm{CO}_{2} \\
\text { Other }\end{array}$ & $\begin{array}{c}10 \\
65 \\
5 \\
9 \\
11\end{array}$ & $\begin{array}{c}\text { Paraffins } \\
\text { Olefins } \\
\text { Cyclo-paraffins } \\
\text { Cyclo-olefins } \\
\text { Aromatics } \\
\text { Other }\end{array}$ & $\begin{array}{c}46 \\
16 \\
8 \\
9 \\
16 \\
5\end{array}$ & $\begin{array}{c}\text { BTX } \\
\text { Phenol } \\
\text { Cresols } \\
\text { Xylenols } \\
\text { Other phenols } \\
\text { Tar bases } \\
\text { Naphthalene } \\
\text { Other aromatics } \\
\text { Pitch }\end{array}$ & $\begin{array}{c}1.5 \\
1.5 \\
4.5 \\
7.0 \\
16.0 \\
2.0 \\
3.5 \\
38.0 \\
26.0\end{array}$ \\
\hline
\end{tabular}

\begin{tabular}{|c|c|c|c|c|c|}
\hline \multicolumn{6}{|c|}{ High-temperature pyrolysis $\left(900-1100^{\circ} \mathrm{C}\right)$} \\
\hline Gas & wt $\%$ & Light oil & wt $\%$ & Tar & wt $\%$ \\
\hline $\begin{array}{l}\mathrm{H}_{2} \\
\text { Hydrocarbons } \\
\mathrm{CO} \\
\mathrm{CO}_{2} \\
\text { Other }\end{array}$ & $\begin{array}{c}50 \\
34 \\
8 \\
3 \\
5\end{array}$ & $\begin{array}{c}\text { BTX } \\
\text { Alicyclics } \\
\text { Aliphatics }\end{array}$ & $\begin{array}{c}89 \\
5 \\
6\end{array}$ & $\begin{array}{c}\text { BTX } \\
\text { Phenols and cresols } \\
\text { Xylenols } \\
\text { Other phenols } \\
\text { Naphthalene } \\
\text { Anthracene } \\
\text { Other aromatics } \\
\text { Tar bases } \\
\text { Pitch }\end{array}$ & $\begin{array}{c}0.6 \\
1.6 \\
0.5 \\
1.0 \\
8.9 \\
1.0 \\
24.6 \\
1.8 \\
60.0\end{array}$ \\
\hline
\end{tabular}




\section{Influence of additives on the devolatilization product yield of typical South African coals}

Radical reactions are the main reactions in the mechanism of tar decomposition and the formation of methane. Radical formation is the rate-determining step in this mechanism. After radical formation, the composition of the gas phase determines the final products of the tar decomposition (Vreugdenhil and Zwart, 2009).

Typical constituents of the light oil, recovered by steam stripping of the liquid tar product from devolatilization, include BTX (benzene, toluene, and xylene), alkanes, cycloalkanes, olefins, and aromatic species (Speight, 1994). Benzol can be produced by the fractional distillation of this oil. After a few washing stages, important BTX products, as well as naphtha, can be recovered by distillation. Benzene extracted from the BTX can be converted into cumene, which can be used to produce synthetic phenol and acetone (Schobert and Song, 2002; Speight, 1994). Valuable compounds obtainable from the tar of coal pyrolysis include many one- to four-ring aromatic and polar compounds. Some of these include phenol, naphthalene, phenanthrene, pyrene, biphenyl, cresol, and pyridine (Schobert and Song, 2002; Speight, 1994). The syntheses of many compounds such as phenolic resins, adipic acid, alkyl-phenols, caprolactam, catechol, and monomers (biphenol A and 2,6-xylenol) are dependent on phenol. An application of 2,6-xylenol is the synthesis of polyphenylene oxide (Schobert and Song, 2002). Various chemicals, specialty chemicals, and solvents can be produced from naphthalene (Song and Moffat, 1994). 2,6dialkyl substituted naphthalene, a monomer feedstock for production of advanced polyester materials, can be produced by alkylation of naphthalene over a molecular sieve. The hydrogenation of naphtalene, on the other hand, produces commercial decalins, which can be used as a thermally stable jet fuel (Song and Schobert, 1993; Schobert and Song, 1995).

Inorganic components in coal have been shown to have a significant effect on coal reactivity (Jenkins, Nandi, and Walker, 1973; Miura, Hashimoto, and Silveston, 1989; Mühlen, Sowa, and van Heek, 1993; Nishiyama, 1991). Differences in the maceral composition, thermoplastic properties, and char morphology limit the study of the effect of mineral matter on coal pyrolysis. However, it has been reported that mineral matter has an effect on many variables related to pyrolysis/gasification, i.e. heating value, coal rank, and ash content (Samaras, Diamadopoulos, and Sakellaropoulos, 1996), final product distribution (Ahmad et al., 2009; Liu et al., 2004; Slaghuis, Ferreira, and Judd, 1991), coal reactivity (Miura, Hashimoto, and Silveston, 1989; Ye, Agnew, and Zhang, 1998), and technological problems such as fouling and slagging (Pusz et al., 1997). The individual effects of minerals can be studied by demineralizing the coal with acid (Hashimoto, Miura, and Ueda, 1986; Kyotani, Herod, and Bartle, 1993; Miura, Hashimoto, and Silveston, 1989).

In a study by Liu et al. (2004), in which coal was selectively demineralized and then devolatilized in order to determine the effect of inorganic material on devolatilization, it was found that the addition of inorganic additives $\left(\mathrm{K}_{2} \mathrm{CO}_{3}\right.$ and $\mathrm{Al}_{2} \mathrm{O}_{3}$ ) to demineralized coal increased the yield of liquid products by up to $11 \%$. It was also determined that the inorganic additives decreased the activation energy for devolatilization, and the characteristic temperature changed
(Liu et al., 2004). In several other studies to determine the effect of inorganic material on devolatilization (without direct loading onto the coal matrix), it was found that magnesium was catalytically active; sodium, calcium, and potassium, however, were ineffective. However, when sodium, calcium, or potassium was loaded directly into the coal matrix these species became highly active (Liu et al., 2004).

Three groups of catalyst materials have been applied in biomass gasification systems - alkali metals, nonmetallic oxides, and supported metallic oxides. Alkali metals are thought to enhance the biomass gasification reactions and therefore are considered primary catalysts and not tar reforming catalysts. Alkali salts are mixed directly with the biomass as it is fed into the gasifier. It is well known from several fundamental studies of cellulose and biomass pyrolysis that alkali metals enhance char formation reactions during thermochemical conversion (Antal and Várhegyi, 1995; Raveendran, Ganesh, and Khilar, 1995, 1996; Richards and Zheng, 1991). The nonmetallic and supported metallic oxide catalysts are usually located in a separate fixed-bed reactor, downstream from the gasifier, to reduce the tar content of the gasification product gas, and are therefore referred to as secondary catalysts. Although the nonmetallic catalysts are sometimes used as bed material in fluidized bed gasifiers to affect tar formation, standalone catalytic reactors can be used with any gasification technology and can be independently controlled to maximize the versatility of the hot gas conditioning process. The most widely studied nonmetallic catalysts for biomass gasifier tar conversion are dolomites (calcium magnesium carbonates).

In a study by Franklin et al. (1981), it was concluded that very few minerals have any effect on the devolatilization behaviour of coal. These discrepancies in results can be attributed to the wide variety of coal compositions and experimental methods used in the numerous studies conducted.

\section{Experimental}

\section{Coal and additive properties}

The coals used in this study (WIR2, WIR4, and WVR5) originate from seams 2, 4, and 5 of the Witbank Coalfield, which is situated between Springs and Belfast in the Mpumalanga Province in South Africa. This coal is currently recovered using opencast mining techniques (Pinheiro, 2010). Ash-free ultimate analyses of the three samples are shown in Table II. Proximate analyses and petrographic results for the three coal samples are shown in Table III.

The characteristics of the inertinite-rich WIR2 and WIR4 coals are very similar. Coal WVR5 differs from both the inertinite-rich coals, due to its higher volatile matter (VM) content and lower fixed carbon (FC) content. A maceral point count analysis of the three coals indicated that coal WVR5 had more vitrinite and liptinite than either of the other coals.

Four additives were selected to study the effect that the different additives have on the tar quantity and quality. Alumina $\left(\mathrm{Al}_{2} \mathrm{O}_{3}\right)$ and three potassium-containing alkali metal salts, i.e. potassium carbonate $\left(\mathrm{K}_{2} \mathrm{CO}_{3}\right)$, potassium acetate ( $\left.\mathrm{CH}_{3} \mathrm{COOK}\right)$, and potassium hydroxide $(\mathrm{KOH})$ were selected based on the work of Liu et al., (2004). The characteristics of 


\section{Influence of additives on the devolatilization product yield of typical South African coals}

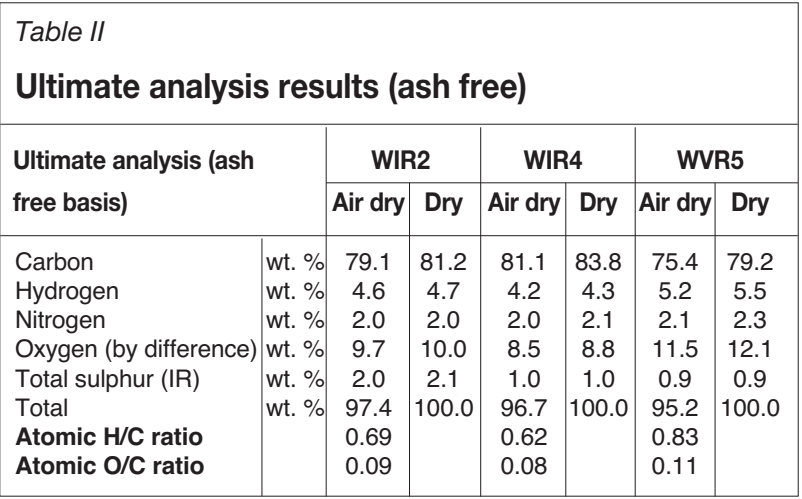

Table III

Proximate and petrographic results

\begin{tabular}{|c|c|c|c|c|c|c|c|}
\hline \multicolumn{2}{|l|}{ Proximate anylysis } & \multicolumn{2}{|c|}{ WIR2 } & \multicolumn{2}{|c|}{ WIR4 } & \multicolumn{2}{|c|}{ WVR5 } \\
\hline & & a.d.b. & d.a.f & a.d.b. & d.a.f & a.d.b. & d.a.f \\
\hline $\begin{array}{l}\text { Inherent moisture } \\
\text { Ash } \\
\text { Volatiles } \\
\text { Fixed carbon } \\
\text { Total } \\
\text { Fuel ratio (FC/VM) }\end{array}$ & $\begin{array}{l}\text { wt. } \% \\
\text { wt. \% } \\
\text { wt. \% } \\
\text { wt. \% } \\
\text { wt. \% }\end{array}$ & $\begin{array}{c}2.1 \\
18.2 \\
25.0 \\
54.7 \\
100.0 \\
2.2\end{array}$ & $\begin{array}{c}- \\
- \\
31.3 \\
68.7 \\
100.0\end{array}$ & $\begin{array}{c}2.8 \\
14.8 \\
24.5 \\
57.9 \\
100.0 \\
2.4\end{array}$ & $\begin{array}{c}- \\
- \\
29.7 \\
70.3 \\
100.0\end{array}$ & $\begin{array}{c}4.2 \\
12.9 \\
32.7 \\
50.2 \\
100.0 \\
1.5\end{array}$ & $\begin{array}{c}- \\
- \\
39.4 \\
60.6 \\
100.0\end{array}$ \\
\hline $\begin{array}{l}\text { Gross calorific value } \\
\text { Grade (based on } C V \text {, } \\
\text { AD basis) }\end{array}$ & $\mathrm{MJ} / \mathrm{kg}$ & & & & & & $\begin{array}{l}8.4 \\
A\end{array}$ \\
\hline \multicolumn{2}{|l|}{ Petrographic analysis } & \multicolumn{2}{|c|}{ WIR2 } & \multicolumn{2}{|c|}{ WIR4 } & \multicolumn{2}{|c|}{ WVR5 } \\
\hline $\begin{array}{l}\text { Total vitrinite } \\
\text { Total liptinite } \\
\text { Reactive semifusinite } \\
\text { Reactive inertodetrinite } \\
\text { Total }\end{array}$ & $\begin{array}{l}\text { vol. } \% \\
\text { vol. } \% \\
\text { vol. } \% \\
\text { vol. } \% \\
\text { vol. } \%\end{array}$ & $\begin{array}{c}33 \\
3 \\
11 \\
6 \\
53\end{array}$ & 3 & $\begin{array}{c}22 \\
3 \\
16 \\
5 \\
46\end{array}$ & & $\begin{array}{r}56 \\
9 \\
6 \\
2 \\
73\end{array}$ & \\
\hline
\end{tabular}

the additives are given in Table IV. The additives were added to the three coals at dosages of of $2.5 \mathrm{wt} . \%, 5 \mathrm{wt} . \%$, and $10 \mathrm{wt} . \%$. Experiments were also conducted on the three coals with no additive. Duplicate experiments were conducted for each test condition, and the tar fractions obtained from each
Table IV

Additive properties

\begin{tabular}{|l|c|c|c|c|}
\hline & $\mathbf{K}_{2} \mathbf{C O}$ & $\mathbf{C H}_{3} \mathbf{C O O K}$ & $\mathbf{A l}_{2} \mathbf{O}_{3}$ & $\mathbf{K O H}$ \\
\hline Name & $\begin{array}{c}\text { Potassium } \\
\text { carbonate }\end{array}$ & $\begin{array}{c}\text { Potassium } \\
\text { acetate }\end{array}$ & $\begin{array}{c}\text { Aluminium } \\
\text { oxide }\end{array}$ & $\begin{array}{c}\text { Potassium } \\
\text { hydroxide }\end{array}$ \\
\hline Physical state & Solid & $\begin{array}{c}\text { Solid } \\
\text { crystalline } \\
\text { powder }\end{array}$ & Solid \\
\hline Melting point & $891^{\circ} \mathrm{C}$ & $292^{\circ} \mathrm{C}$ & $2072^{\circ} \mathrm{C}$ & $380^{\circ} \mathrm{C}$ \\
\hline Boiling point & Decomposes & Decomposes & $2980^{\circ} \mathrm{C}$ & $1384^{\circ} \mathrm{C}$ \\
\hline $\begin{array}{l}\text { Molecular weight } \\
\text { (g/mol) }\end{array}$ & 138.21 & 98.14 & 101.96 & 56.11 \\
\hline Purity & $>99.99 \%$ & $>99.99 \%$ & $>99.99 \%$ & $>99.99 \%$ \\
\hline Supplier & Sigma Aldrich & & & \\
\hline
\end{tabular}

experiment were analysed individually. The errors based on the standard deviation for duplicate experiments and a 95\% confidence interval were deemed acceptable for use to identify significant changes.

To establish a comparative baseline for the coals used in this study, samples of the three coals were subjected to the modified Fischer tar assay method; details of which have been reported elsewhere (Roets et al., 2014). Figure 1 shows a schematic of the modified Fischer Assay experimental setup that was recently developed in order to perform Fischer Assay experiments at temperatures above the ISO 647 temperature of $520^{\circ} \mathrm{C}$. The modifications include the use of stainless steel retorts instead of aluminium in order to operate at temperatures close to $1000^{\circ} \mathrm{C}$ and the capture of non-condensable gases in gas sampling bags. The gas formed during the heating of the coal and pyrolysis flows through stainless steel pipes and is bubbled though a tar trap and two gas wash bottles. This is done in order to capture the condensable gases (tar and water vapour) before the noncondensable gases are captured in $10 \mathrm{~L}$ Tedlar gas sampling bags. Toluene is used as solvent in the tar trap and gas wash bottles, and is kept at $0^{\circ} \mathrm{C}$ by immersion in an ice bath.

Two stainless steel retorts, built according to ISO 647 dimensions, are used to contain the $50 \mathrm{~g}$ coal samples with

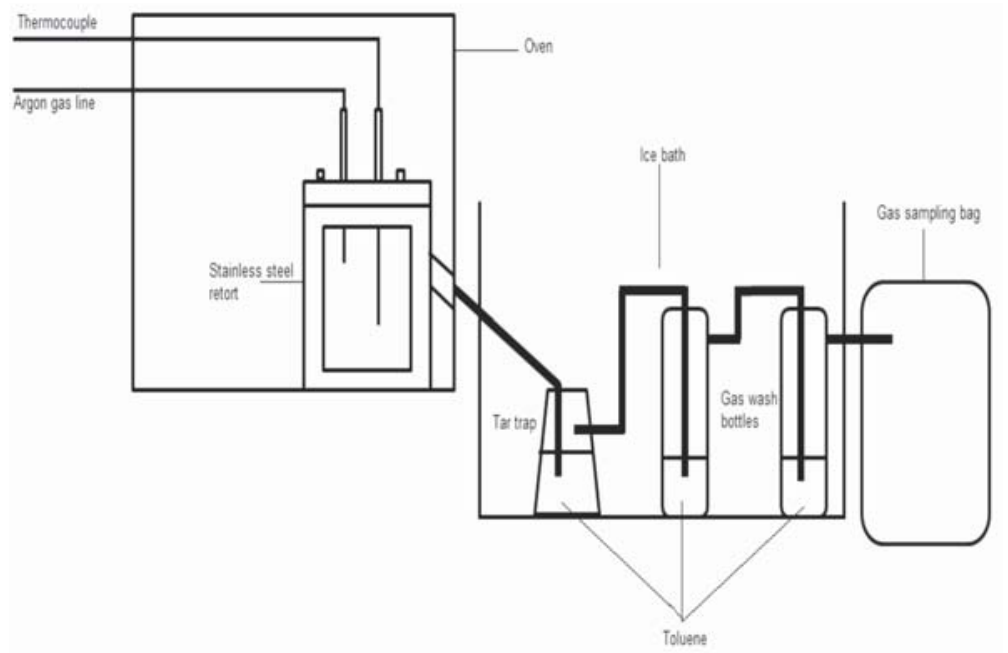

Figure 1-Schematic of the Fischer Assay experimental set-up 


\section{Influence of additives on the devolatilization product yield of typical South African coals}

particle size $90 \%<1 \mathrm{~mm}$, not more than $50 \%<0.2 \mathrm{~mm}$. The coal is heated in an argon atmosphere in order to prevent combustion. The retorts are heated in a Lenton oven (22 A, $48 \mathrm{~kW}$ rating over $220 \mathrm{~V}$ ) fitted with a TOHO TTM-P4 temperature controller and a Shinko LMD-100 console/data logger. Two K-type thermocouples are fitted in each of the two retorts, one measuring the bed temperature and the other the temperature inside the oven chamber. A lag in temperature increase between the oven chamber temperature and the bed temperature exists; therefore the bed temperature was used for temperature control. The heating rate ranged between $8.5^{\circ} \mathrm{C} / \mathrm{min}$ and $9.5^{\circ} \mathrm{C} / \mathrm{min}$, depending on the final pyrolysis temperature of $520^{\circ} \mathrm{C}$. The work was conducted under atmospheric pressure $(87.5 \mathrm{kPa})$.

Fischer Assay product mass yields derived from the coal include char, tar, water, and gas. All these products are captured in the closed system. The mass yields (on an 'asanalysed' basis) are determined by the following equations:

$$
\begin{aligned}
& \text { Char yield }(w t \%)=\frac{m_{4} \times 100}{m_{0}} \\
& \text { Tar yield }(w t \%)=\frac{\left(m_{2}-m_{1}-m_{3}\right) \times 100}{m_{0}} \\
& \text { Water yield (decomposition), wt } \%=\frac{m_{3} \times 100}{m_{0}}-M \\
& \text { Gas yield, wt } \%=\frac{\left(m_{0}+m_{1}-m_{2}-m_{4}\right) \times 100}{m_{0}}
\end{aligned}
$$

where

$m_{0}$ is the sample mass

$m_{1}$ is the mass of the empty receiver and stopper

$m_{2}$ is the mass of $m_{1}$ plus tar plus total water

$m_{3}$ is the mass of total water determined

$m_{4}$ is the mass of char

$M$ is the inherent moisture content of the coal sample.

Yields on a dry basis can be determined multiplying the above equations by:

$$
\frac{100}{100-M}
$$

\section{Char yield}

The char yield was determined by weighing the residue retained in the retorts (after it was left to cool to room temperature) on a mass balance and with the use of Equation [1]. The chars were stored in airtight containers after purging with argon in order to prevent oxidation before characterization was done.

\section{Water yield}

Dean-Stark distillation was used in order to determine the total water yield. The liquid obtained from the tar trap and two gas wash bottles, containing toluene, water, and tar, was placed in a round-bottomed flask inside a Seta MTop 5 heating mantle. This mixture was heated and the evaporated components were condensed using a reflux condenser and captured in a reflux reservoir. The condensed liquid contained the water, toluene, and light tar components. The higher density $\left(998 \mathrm{~kg} / \mathrm{m}^{3}\right)$ polar liquid (water) separated from the lower density $\left(865 \mathrm{~kg} / \mathrm{m}^{3}\right)$ non-polar liquid (toluene) and could easily be decanted and weighed.

\section{Tar yield}

The mixture of toluene and tar, after the water has been removed by Dean-Stark distillation, was transferred into a round-bottomed flask connected to a Büchi Rotavapor R II. The pressure inside the system was gradually decreased from atmospheric to 27 mbar, while the toluene-tar mixture was kept at $60^{\circ} \mathrm{C}$. A Büchi V-850 vacuum controller and V-700 vacuum pump were used to obtain this pressure. The pressure was held for at least 5 minutes in order to ensure that all the toluene was removed from the flask. The mass of the flask was determined after evaporation and the tar yield was determined using Equation [2].

\section{Gas yield}

The gas yield was determined by difference using Equation [4].

The results obtained from the modified Fisher Assay method were compared with the standard ISO Fischer assay method (SANS 1974); results are given in Table V.

Both methods showed that all the raw coals produced significant amounts of tar, with coal WVR5 producing the highest amount (11 wt.\%). In order to calculate the additivefree mass of the char, the volatilization of the additive must be taken into account. The amount of additive volatilized at $520^{\circ} \mathrm{C}$ was determined by heating the pure additive in a thermogravimetric analyser (TGA) and measuring the mass loss as the temperature increased.

In the absence of catalysts:

$$
Y_{\text {char }}=\frac{m_{\text {char }}}{m_{t}}
$$

where the total mass is $m_{t}=\frac{\left(m_{\text {char }}+m_{\text {water }}+m_{\text {tar }}+m_{\text {gas }}\right)}{1}$

When a catalyst is used, and to account for the partial decomposition of the catalyst at $T=520^{\circ} \mathrm{C}$, the yield is redefined to account for the presence of the remaining catalyst in the solid fraction as follows:

$$
Y 1_{\text {char }}=\frac{m_{\text {char }}-m_{\text {cat }, T}}{m_{t}-m_{\text {cat }, T}}
$$
basis.

All results reported in this paper are calculated on this

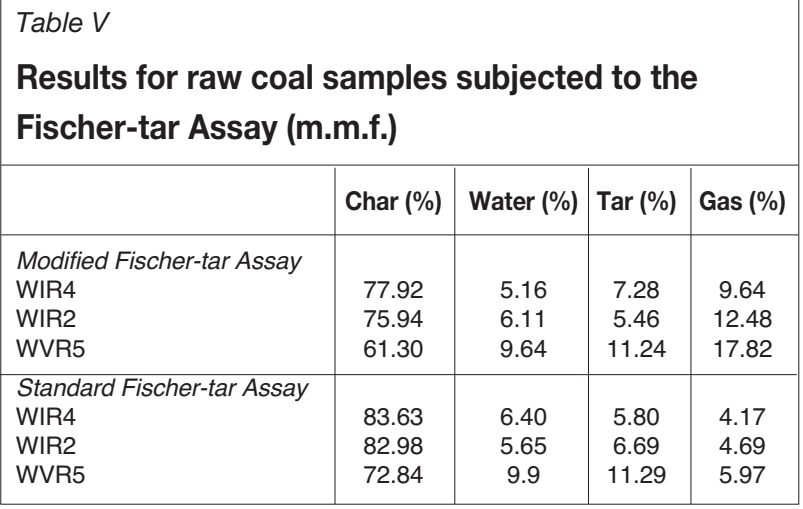




\section{Influence of additives on the devolatilization product yield of typical South African coals}

\section{Tar analysis}

Simulated distillation analysis was conducted according to the ASTM D2887 standard as reported previously (Roets et al., 2014). Petrochemical products were categorized into boiling point ranges using simulated distillation, a standard used for fractions with a boiling range between $55.5^{\circ} \mathrm{C}$ and $538^{\circ} \mathrm{C}$ (Ukwuoma, 2002). This analysis was done for all experimentally generated tars. A Perkinelmer Clarus 500 HT5 aluminium-clad fused silica capillary column with $25 \mathrm{~m}$ length and an ID of $0.32 \mathrm{~mm}$ was used for this analysis. An FID detector was used and helium was applied as the carrier gas at a flow rate of $10 \mathrm{~mL} / \mathrm{min}$. The program was set to an injection temperature of $350^{\circ} \mathrm{C}$ and the detector temperature at $370^{\circ} \mathrm{C}$. The first ramp was at $15^{\circ} \mathrm{C} / \mathrm{min}$ from $35^{\circ} \mathrm{C}$ to $350^{\circ} \mathrm{C}$ and was held for 2 minutes. A second ramp was introduced at a heating rate of $25^{\circ} \mathrm{C} / \mathrm{min}$ to $380^{\circ} \mathrm{C}$ and was held for 10 minutes. Only the fractions with boiling points lower than $450^{\circ} \mathrm{C}$ were analysed. From petroleum cut-tables, the boiling points are generally categorized as follows: heavy naptha $\left(<205^{\circ} \mathrm{C}\right)$, kerosene $\left(205-260^{\circ} \mathrm{C}\right)$, diesel $\left(260-340^{\circ} \mathrm{C}\right)$, gas oil $\left(340-425^{\circ} \mathrm{C}\right)$, and residue fraction $\left(425-450^{\circ} \mathrm{C}\right)$.

The SEC-UV analyses of the derived tars were carried out by high-performance liquid chromatography (HPLC) using an Agilent 1100 instrument set at $80^{\circ} \mathrm{C}$ with a $300 \mathrm{~mm}$ long, $7.5 \mathrm{~mm}$ internal diameter PLgel mixed-E (Varian) GPC column for separation and HPLC grade 1-methyl-2pyrollidone (NMP) from Merck Chemicals at a flow rate of $0.5 \mathrm{ml} / \mathrm{min}$ as eluent. Integration and peak identification of the SEC-UV data was done using the HP 1100 data analysis software.

Characterization of the coal tar derived from the additivemixed coal samples was completed by investigating the effect that the additives had on the structure of the coal tar samples. The NMR method, as described by Morgan, George, and Davis, (2008) was used for investigating the tar structure. The samples were mixed with a dichloromethane (DCM) solvent, ferric acetylacetonate $(\mathrm{Fe}(\mathrm{acac}) 3$ ) relaxation agent, and tetrakis(trimethylsilyl) silane (TKS) internal standard the concentrations shown in Table VI. The samples were then analysed at $600 \mathrm{MHz}$ for proton NMR analysis and at $150 \mathrm{MHz}$ for carbon NMR analysis. The analyses were carried out at a working temperature of $35^{\circ} \mathrm{C}$.

\section{Results and discussion}

\section{Product yield}

Fischer Assay experiments were conducted with additives ranging from zero to $10 \mathrm{wt} \%$. The effects on the char and tar product yields are shown in Figures 2 to 5. Bars in the positive region of the graphs indicate an increase in relation to the raw coal without additive, and those in the negative region a decrease .

It was noted that although the additive had an effect on all the coals used in this study, the magnitude of the effect varied with coal type. Product quantity from the WIR2 coal showed little to no change when additive load was increased, whereas for the WIR4 and WVR5 coals, changes in tar yield in relation to the raw coal without additive ranged significantly between $15 \%$ and $48 \%$ for a $10 \%$ additive load. Table VII summarizes the results regarding tar product yields obtained at $10 \%$ additive load. It can be observed that less tar was produced in all cases, meaning that the additive has an effect on tar yield irrespective of additive type. Similar results were observed by other researchers (Franklin et al., 1981, 1983, Howard, 1981, Mori et al., 1996, Hayashi et al., 2000). The reason why the WIR2 coal char yield is largely unaffected by the additives is not currently understood.

\section{Tar composition}

Tar composition is highly dependent on the maceral content of the coal feedstock to the extent where variations in the vitrinite composition affect the tar composition (Pan et al., 2011). In general, coal containing high amounts of vitrinite

Table VI

NMR sample preparation concentrations

\begin{tabular}{|l|c|c|}
\hline Sample solution & 1H-NMR & 13C-NMR \\
\hline Sample weight $(\mathrm{mg})$ & 200 & 200 \\
Fe(acac) 3 weight $(\mathrm{mg})$ & $<3.0$ & 30 \\
Sample + solvent volume (mL) & 1 & 1 \\
Sample concentration $(\% \mathrm{w} / \mathrm{v})$ & 20 & 20 \\
Fe(acac) 3 concentration $(\% \mathrm{w} / \mathrm{v})$ & $0.0-0.3$ & 3 \\
Reference material (TKS) weight (mg) & 10 & 20 \\
\hline
\end{tabular}

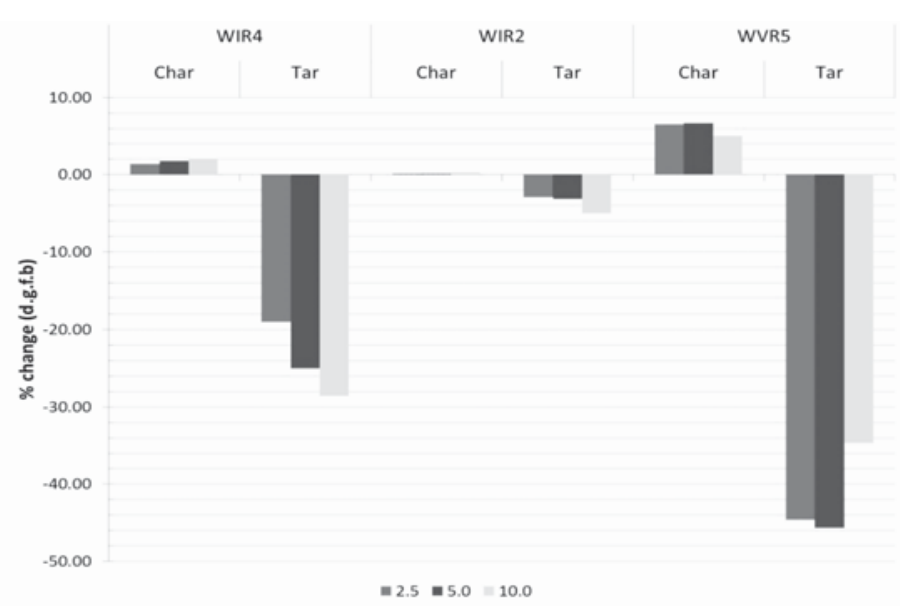

Figure 2-Change in product yield with additive load $\mathrm{K}_{2} \mathrm{CO}_{3}$ 
Influence of additives on the devolatilization product yield of typical South African coals

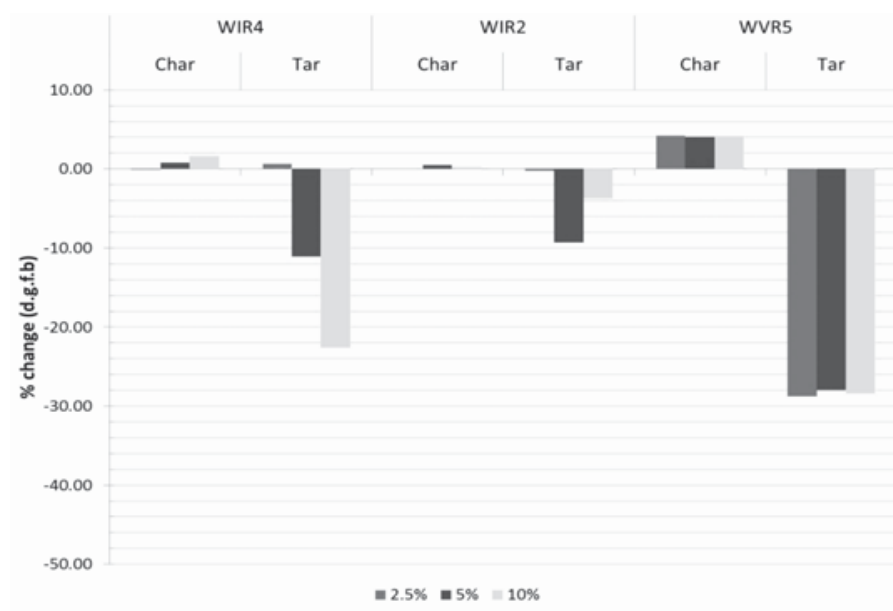

Figure 3-Change in product yield with additive load $\mathrm{CH}_{3} \mathrm{COOK}$

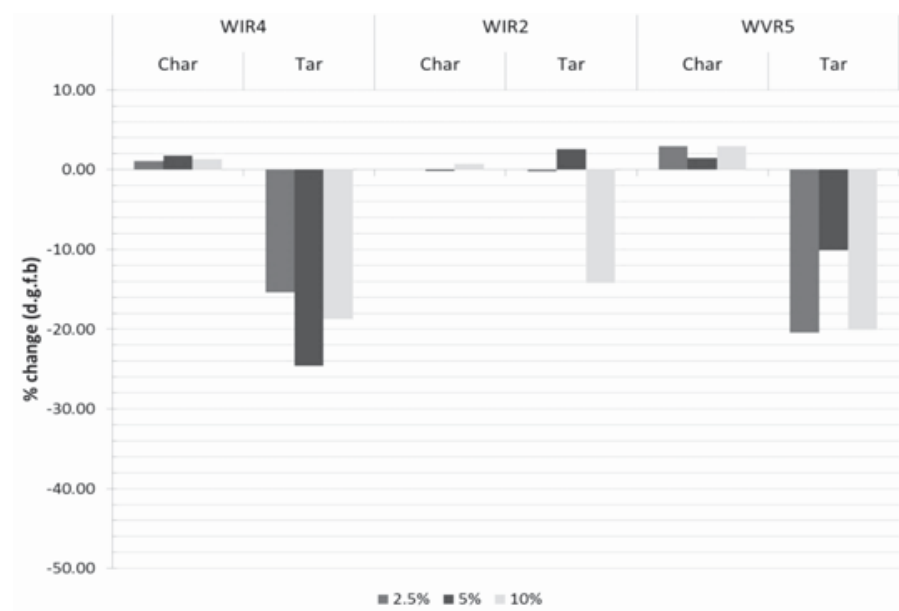

Figure 4-Change in product yield with additive load $\mathrm{Al}_{2} \mathrm{O}_{3}$

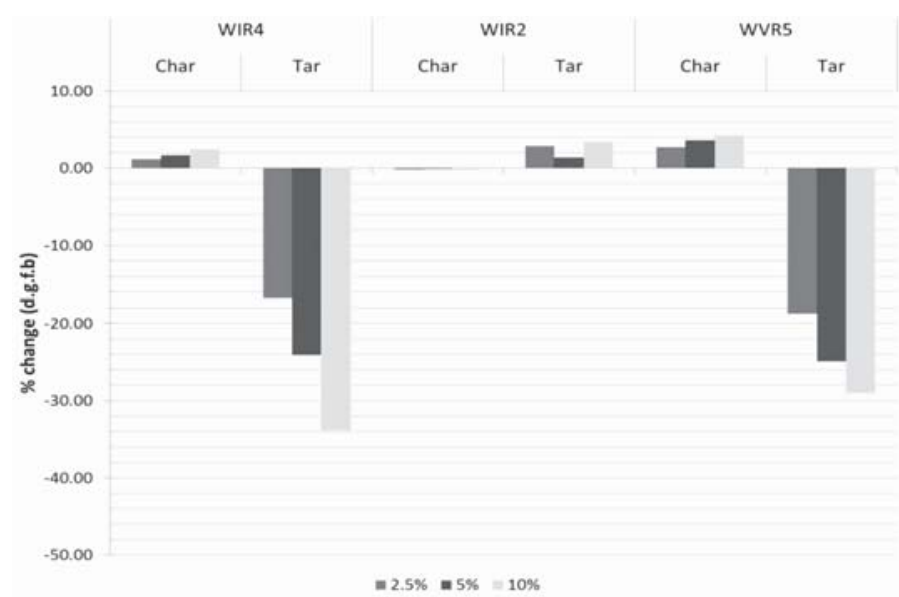

Figure 5-Change in product yield with additive load $\mathrm{KOH}$

produces tars with higher levels of hydrocarbons and condensed aromatic systems (Iglesias et al., 2001; Pan et al., 2011). Tar composition was analysed using size exclusion chromatography, simulated distillation, and nuclear magnetic resonance.
Size exclusion chromatography (SEC)

Figures 6 to 9 show the changes in light and heavy components for each of the additives used: see Table VIII for an explanation of the coal-additive mixture in these Figures. 


\section{Influence of additives on the devolatilization product yield of typical South African coals}

\begin{tabular}{|c|c|c|c|}
\hline \multicolumn{4}{|c|}{$\begin{array}{l}\text { Liquid product yields for raw coal vs. additive } \\
\text { loaded coal (10 wt. } \%)\end{array}$} \\
\hline Coal & $\%$ tar from raw coal & $\%$ tar from additive coal & Additive \\
\hline WIR4 & 5.82 & 4.28 & \multirow{3}{*}{$\mathrm{K}_{2} \mathrm{CO}_{3}$} \\
\hline WIR2 & 4.38 & 4.45 & \\
\hline WVR5 & 9.78 & 7.16 & \\
\hline WIR4 & 5.82 & 4.87 & \multirow{3}{*}{$\mathrm{CH}_{3} \mathrm{COOK}$} \\
\hline WIR2 & 4.38 & 4.38 & \\
\hline WVR5 & 9.78 & 7.79 & \\
\hline WIR4 & 5.82 & 5.09 & \multirow{3}{*}{$\mathrm{Al}_{2} \mathrm{O}_{3}$} \\
\hline WIR2 & 4.38 & 4.01 & \\
\hline WVR5 & 9.78 & 9.32 & \\
\hline WIR4 & 5.82 & 4.12 & \multirow{3}{*}{$\mathrm{KOH}$} \\
\hline WIR2 & 4.38 & 4.57 & \\
\hline WVR5 & 9.78 & 8.06 & \\
\hline
\end{tabular}

It can be observed that, in general, as the additive load is increased, the heavy component fraction decreases (mainly from $2 \%$ to $5 \%$ ) with a subsequent change in the light component fraction. The effect of additional mineral matter on the devolatilization products from low-temperature carbonization may be attributed to the promotion of secondary hydrocarbon cracking. This is most evident in the case of the WVR5 coal, where the increase in lower weight components with the subsequent reduction in higher weight components indicates a transformation of the product composition. This is discussed further in the nuclear magnetic resonance $13 \mathrm{C}$-NMR and $1 \mathrm{H}-\mathrm{NMR}$ results to follow.

\section{Simulated distillation (SimDis)}

Figure 10 shows the recovered tar mass $v s$. boiling point for the WIR2 coal tar using $\mathrm{KOH}$ as additive. The data indicates that after the initial mass loss (incurred when the samples are heated to $200^{\circ} \mathrm{C}$ ), the tars lose mass at a constant rate with increasing temperature. A comparison of the tar recovery $v s$. boiling point trend for the parent coal with the trend lines for the coal-additive mixtures indicates that the temperature needed to reach $100 \%$ mass loss of tar is substantially higher $\left(540^{\circ} \mathrm{C}\right)$ than for the tar derived by $\mathrm{KOH}$ addition $\left(390^{\circ} \mathrm{C}\right)$.

These lower temperatures observed for the tar samples derived from additive-mixed coals are indicative of a tar that has a lighter average composition (ECHA, 2009). Using this metric, the tars produced in the presence of an additive can be considered to have been chemically altered to have a lower average molecular mass.

The weighted average boiling point (WABP) is determined by Equation [9] (Iglesias et al., 2001).

$$
W A B P=\frac{T_{10}+T_{30}+T_{50}+T_{70}+T_{90}}{5}
$$

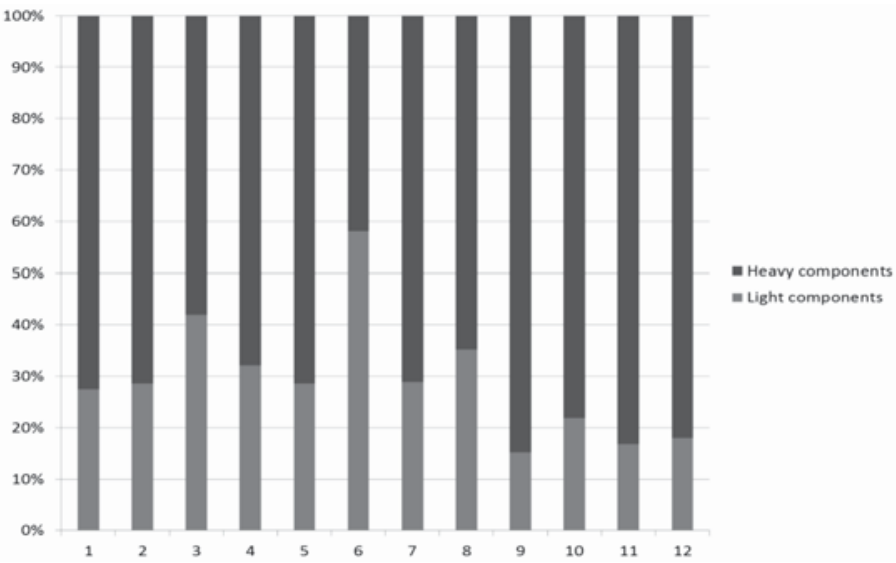

Figure 6-SEC $\mathrm{K}_{2} \mathrm{CO}_{3}$ results - comparison of light and heavy tar fractions

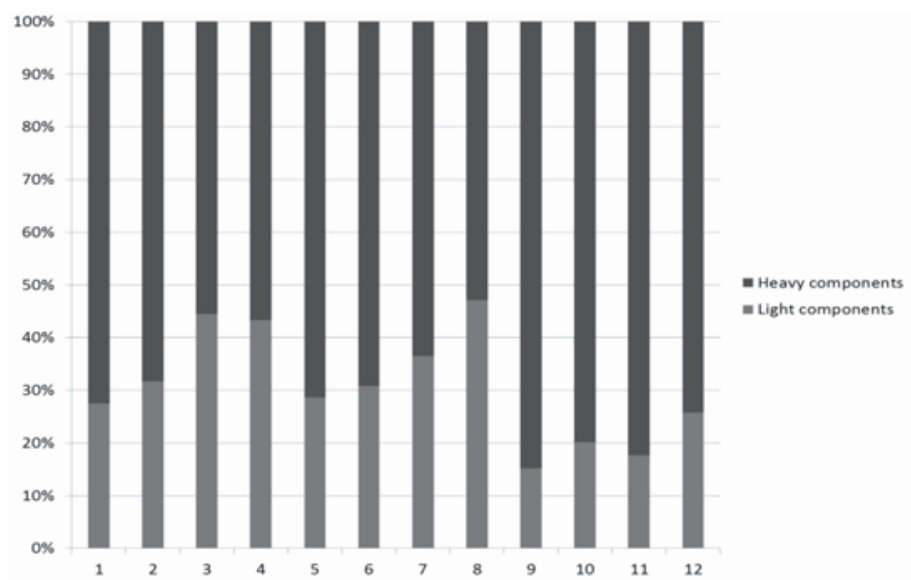

Figure 7-SEC $\mathrm{CH}_{3} \mathrm{COOK}$ results - comparison of light and heavy tar fraction 


\section{Influence of additives on the devolatilization product yield of typical South African coals}

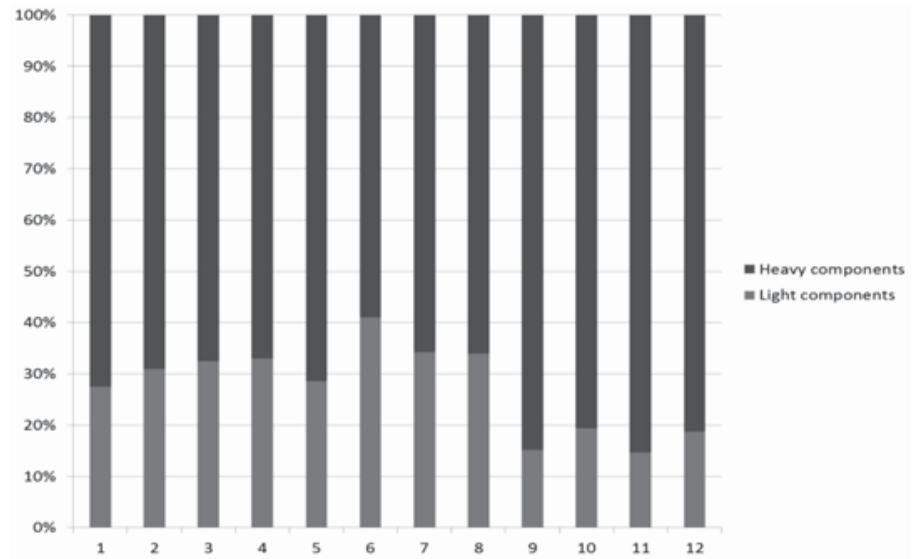

Figure 8-SEC $\mathrm{Al}_{2} \mathrm{O}_{3}$ results - comparison of light and heavy tar fractions

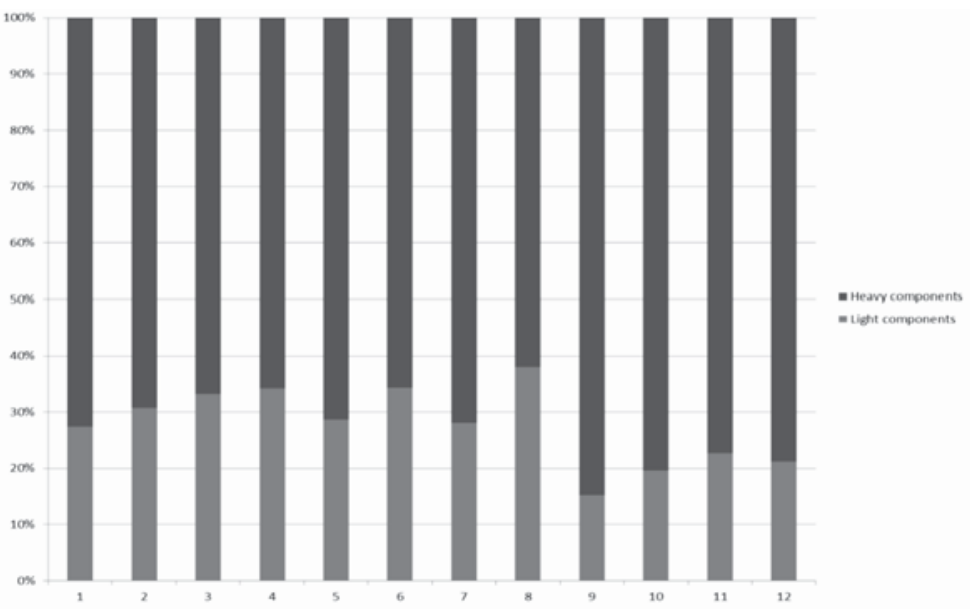

Figure 9-SEC KOH results - comparison of light and heavy tar fractions

Table VIII

\section{Clarification of coal additive mixture}

\begin{tabular}{|l|c|c|c|c|}
\hline & Parent & $\mathbf{2 . 5} \%$ & $\mathbf{5} \%$ & $\mathbf{1 0 \%}$ \\
\hline WIR4 & 1 & 2 & 3 & 4 \\
WIR2 & 5 & 6 & 7 & 8 \\
WVR5 & 9 & 10 & 11 & 12 \\
\hline
\end{tabular}

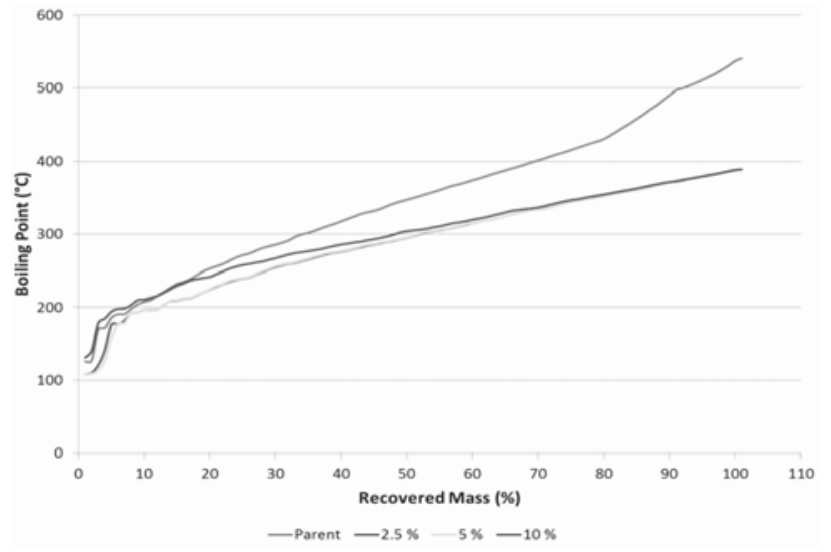

Figure 10-Recovered mass vs. boiling point for WIR2 coal mixed with $\mathrm{KOH}$ additive where the subscripts denote the percentage mass loss and $T$ denotes the boiling-point temperature.

Results for the average boiling point analyses are given in Figures 11 to 14. It can be observed that a decrease in weighted average boiling point (WABP) occurs with an increase in additive load, with minor exceptions. For all additive loads of $2.5 \%$, the average boiling point decreased irrespective of the coal used. As the additive load is increased further, the boiling point for the $\mathrm{K}_{2} \mathrm{CO}_{3}$ samples increase for both coals WIR2 and WVR5, resulting in a WABP which is higher at $10 \%$ load than with zero load. This same trend of optimal additive load can be observed for $\mathrm{CH}_{3} \mathrm{COOK}$, where, the maximum reduction in WABP is observed at $5 \%$ additive load. The effect of the $\mathrm{Al}_{2} \mathrm{O}_{3}$ additive on WABP becomes significant only at loads above $5 \%$. In order to determine which additive is the most effective, the reductions in the WABP caused by the different additives were compared. The most effective additive tested in this study for the reduction of the WABP of liquid products is $\mathrm{KOH}$, with a significant reduction in $\mathrm{WABP}\left(>50^{\circ} \mathrm{C}\right)$ observed at $2.5 \%$ load; this reduction is largely sustained at higher additive loads.

The WIR4 coal values from Figure 11 shows that the $\mathrm{WABP}$ is $359^{\circ} \mathrm{C}$; when the additive load is increased to $2.5 \%$ the WABP drops to $308^{\circ} \mathrm{C}$, which indicates a much lower average molecular mass tar being produced. With a further increase in additive load to $10 \%$, the WABP increases to 


\section{Influence of additives on the devolatilization product yield of typical South African coals}

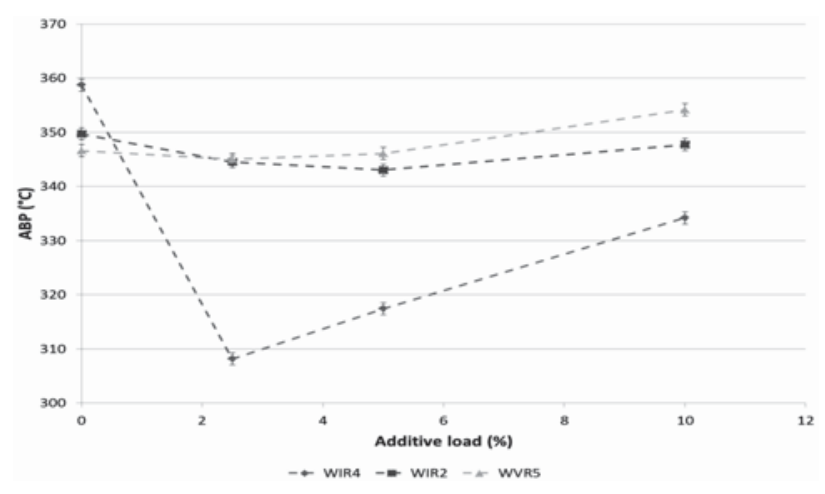

Figure 11-Average boiling point of tar derived from coals with additive $\mathrm{K}_{2} \mathrm{CO}_{3}$

$334^{\circ} \mathrm{C}$. This shows that the optimal load is $2.5 \%$ addition, for reasons that are currently not clear. For coals WIR2 and WVR5, $\mathrm{K}_{2} \mathrm{CO}_{3}$ had a much smaller effect with regard to lowering of WABP, with both these coals undergoing minimal change in WABP at $10 \%$ additive load.

When taking into account the decomposition of the additives, in all cases it was noted for the WVR5 coal that the CH3COOK additive (Figure 12) caused an increase in WABP when the load was increased to $10 \%$. Coals WIR4 and WIR2 showed a significant decrease in WABP at $5 \%$ additive loading, while at $10 \%$ additive loading this trend reversed with a large increase in WABP occurring for both coals. With $\mathrm{Al}_{2} \mathrm{O}_{3}$ additive (Figure 13) the WIR2 and WVR5 coals underwent only small changes at low additive loadings, while the WIR 4 coal underwent a $25^{\circ} \mathrm{C}$ lowering of the WABP at $2.5 \%$ and $5 \%$ additive loadings. At $10 \%$ additive loading, all three coals underwent large changes to end at lower WABP values.

The KOH additive (Figure 14) showed no clear optimal loading, with the additive causing significant changes (even at low loadings these changes were sustained). When the additive loads were increased to $10 \%$, the coal WIR4 tar product had a final WABP $80^{\circ} \mathrm{C}$ lower than the tar product of the parent material. The decrease in average boiling points compares well with results obtained from the SEC analyses, indicating a lower average molecular mass, which would lead directly to a decrease in WABP.

The SimDist boiling points obtained in this study were further characterized using petroleum cut-tables. Based on inference from Figure 10, the recovered mass (\%) yields were:

(1) Heavy naphtha: 9\%, 10\%, and 15\% for the parent coal, $2.5 \%$ additive addition, and $5 \%$ additive addition respectively

(2) Kerosene: $11 \%, 13 \%$, and $15 \%$ for the parent coal, $2.5 \%$ additive addition, and $5 \%$ additive addition respectively

(3) Diesel: $28 \%, 49 \%$, and $42 \%$ for the parent coal, $2.5 \%$ additive addition, and $5 \%$ additive addition respectively

(4) Gas oil: $28 \%, 0 \%$, and $0 \%$ for the parent coal, $2.5 \%$ additive addition, and $5 \%$ additive addition respectively

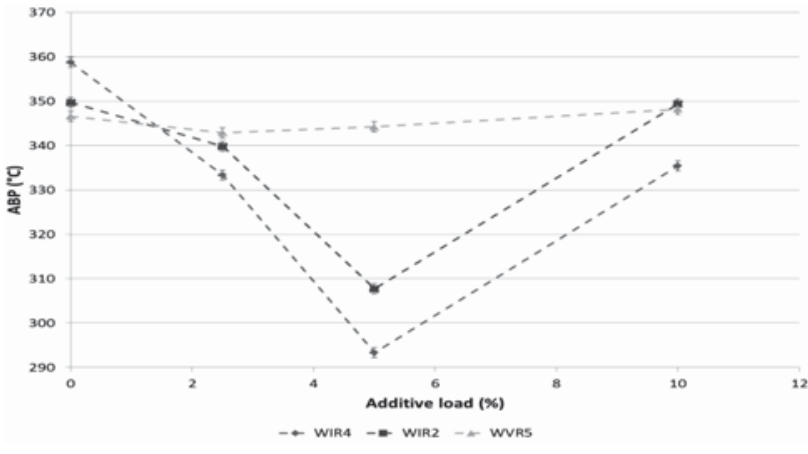

Figure 12-Average boiling point of tar derived from coals with additive $\mathrm{CH}_{3} \mathrm{COOK}$

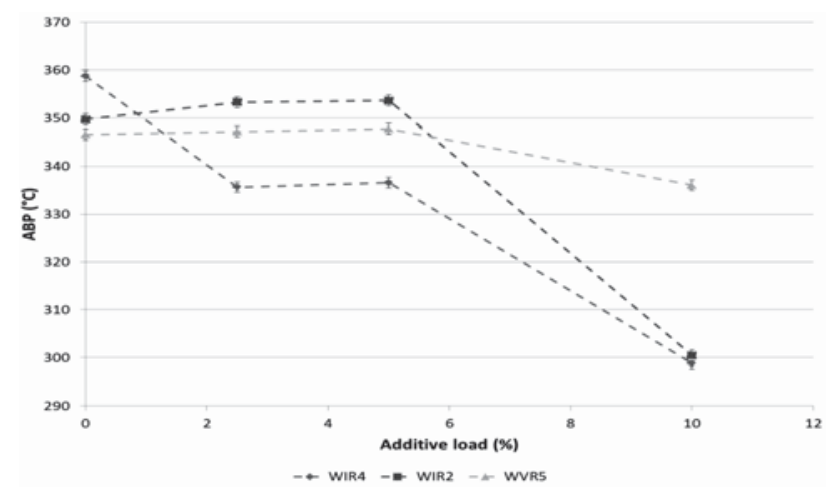

Figure 13-Average boiling point of tar derived from coals with additive $\mathrm{Al}_{2} \mathrm{O}_{3}$

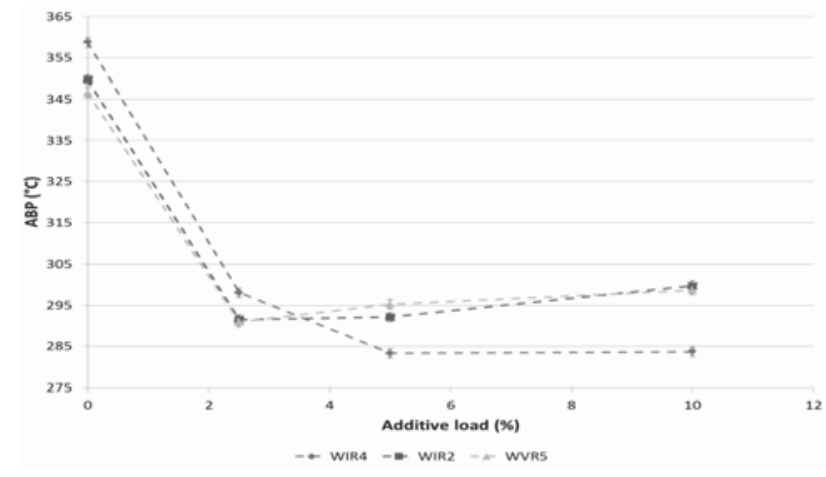

Figure 14-Average boiling point of tar derived from coals with additive $\mathrm{KOH}$

(5) Residue fraction: $8 \%, 0 \%$, and $0 \%$ for the parent coal, $2.5 \%$ additive addition, and $5 \%$ additive addition respectively.

These results show conclusively that lower boiling-point petroleum products were produced when additives were reacted together with coal and pyrolysed at $520^{\circ} \mathrm{C}$.

\section{Nuclear magnetic resonance}

The results of the 13C-NMR and the 1H-NMR analyses for coal with $\mathrm{K}_{2} \mathrm{CO}_{3}$ additive are given in Tables IX and X respectively. The changes observed in the $13 \mathrm{C}$-NMR analysis of the WIR4 coal tar indicate that as the additive load is 


\section{Influence of additives on the devolatilization product yield of typical South African coals}

\begin{tabular}{|c|c|c|c|c|}
\hline \multicolumn{5}{|c|}{$\begin{array}{l}\text { Table IX } \\
\text { 13C-NMR chemical shift summary for coal WIR4 } \\
\text { with additive } \mathrm{K}_{2} \mathrm{CO}_{3}(\%)\end{array}$} \\
\hline \multirow{2}{*}{$\begin{array}{l}\text { Chemical shift range } \\
(\mathrm{ppm})\end{array}$} & \multicolumn{4}{|c|}{ Fraction (\%) } \\
\hline & $0 \%$ & $2.5 \%$ & $5 \%$ & $10 \%$ \\
\hline $17-23$ & 7.13 & 4.08 & 7.57 & 8.02 \\
\hline $23-29.5$ & 6.97 & 3.11 & 11.14 & 5.85 \\
\hline $29.5-34$ & 6.50 & 7.94 & 4.37 & 12.28 \\
\hline $34-39.5$ & 4.01 & 3.67 & 3.23 & 5.32 \\
\hline $39.5-49.3$ & 2.11 & 1.71 & 1.01 & 2.29 \\
\hline $108-129.5$ & 45.99 & 43.80 & 51.23 & 47.06 \\
\hline $129.5-160$ & 27.29 & 35.69 & 21.44 & 27.21 \\
\hline
\end{tabular}

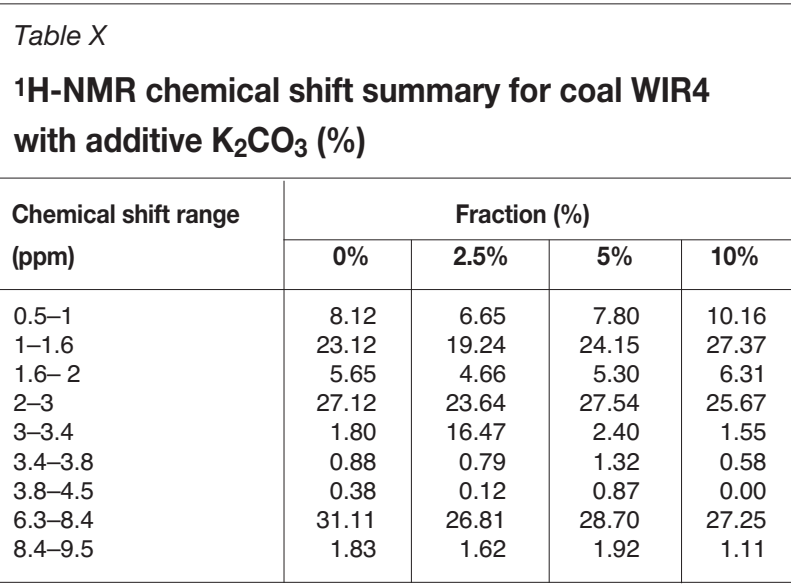

increased to $2.5 \%$, the aromatic fraction of the coal increases (from $73.3 \%$ to $79.5 \%$ ). This increase does not occur at higher additive loadings. The largest contribution to the increase in aromatic fraction is for the peri-condensed or protonated aromatic carbons (108-129.5 chemical shift).

With regard to the hydrogenated aliphatic ranges, increases are noted for the ethyl and propyl groups at 5\% additive loading; this increase occurs only at $5 \%$ additive loading, with both the $2.5 \%$ and $10 \%$ additive loadings resulting in a decrease in the ethyl and propyl groups. The increases in ethyl and propyl groups indicate greater sidechain lengths for this coal tar. Acenaphthene-type methylene (29.5-34 chemical shift) increases at higher additive loadings, with the maximum increase occurring at $10 \%$ loading, where the fraction doubles to $12.3 \%$.

$1 \mathrm{H}-\mathrm{NMR}$ analysis indicates that the fraction of aromatic hydrogen compounds decreases at higher additive loads. This decrease is caused by a decrease in both non-sterically hindered and general aromatic hydrogen. When the additive load is increased beyond $2.5 \%$, an increase in aliphatic hydrogen in methyl or methylene $\beta$ compounds is noted, reaching a maximum at $10 \%$ additive loading, with the methyl or methylene compound fraction increasing to $27.4 \%$ from $23.1 \%$ at no additive loading.

\section{Likely mechanisms}

Several possible causes have been identified for this tendency of tar yield reduction, which depends strongly on the inherent and additional minerals present during the devolatilization process. Franklin et al. $(1981,1983)$ postulated that the reduction in liquid product yields with the addition of minerals is due to catalysis of secondary hydrocarbon cracking/repolymerization reactions. In a study by Wornat and Nelson (1992), a reduction in liquid hydrocarbon product yields was attributed to either the promotion of tar-to-char reaction by the additive, or to the tightening of the coal structure (reduction in pore diameter), which ultimately increases the resistance to the transport of larger tar molecules from the structure. Thus, from a kinetic perspective, the longer the condensable tar-forming fraction is held within the coal structure, the more it will crack to carbon and lighter hydrocarbons.

Based on the results in Figures 2 to 5 , the reduction in liquid product yield noted in this study may be a combination of all three postulated mechanisms. The catalysis of secondary hydrocarbon cracking/repolymerization reactions was investigated using SEC, and from the increase in char mass with an increase in additive loading, the tar-to-char reactions are most likely favoured. The proximate analysis (a.f.b.) of the additive char samples compared to that of raw coal samples suggests that the promotion of tar-to-char reactions not only helps to explain the reduction in tar yield, but also may account for the observed increase in char mass.

\section{Conclusion}

Using the Fischer Assay analysis method, the quantities of both liquid (tar) and solid (char) products were found to be influenced by the addition of additives for the three coals tested. The liquid product yield generally decreased as the additive load increased, with vitrinite-rich coal (WVR5) displaying the largest changes (up to $50 \%$ reduction) when mixed with $\mathrm{K}_{2} \mathrm{CO}_{3}$. Inertinite-rich coal (WIR4) also showed significant decreases in liquid product yield (10-40\% decrease) with any of the additives. The reduction in liquid product yield was lowest for the inertinite-rich WIR2 coal, with a maximum reduction of $14 \%$ at $10 \% \mathrm{Al}_{2} \mathrm{O}_{3}$ addition.

On the other hand, with increasing additive load, coals WIR4 and WVR5 yielded a higher mass of solid product compared to the WIR2 coal. The yield of char derived from WIR4 increased (on average by 2\%) over the range of additives used in this study. This effect was much more pronounced for coal WVR5, with an average increase in char mass of $5 \%$ over the range of additives tested. On the contrary, Fischer Assay analysis of coal WIR2 indicated little to no effect of additives on char yield.

Size exclusion chromatography (SEC) showed that the tar products derived in the presence of additives contained a lower fraction of heavy components (above $400 \mathrm{MM}$ ), and a lighter average light component (below $400 \mathrm{MM}$ ). The changes noted for the heavy components of tars derived from coals WIR2 and WIR4 were not reflected in the tar derived from coal WVR5 in that the heavy component fraction was not reduced.

Analysis of the coal tars by simulated distillation supported the results derived from the SEC analysis in that it showed a reduction in WABP as the additive loading increased to $10 \%$; this is indicative of a lower average molecular weight tar being produced. Investigation of the structure of the coal tars derived from coal WIR4 with $\mathrm{K}_{2} \mathrm{CO}_{3}$ additive indicated that as the additive load increased the 


\section{Influence of additives on the devolatilization product yield of typical South African coals}

fraction of aromatic carbons increased; this was accompanied by a reduction in aromatic hydrogen. Changes in the chemical shift integration analyses of the NMR data also pointed to a reduction in side chain length at higher additive loadings.

When the results from the Fisher Assay analysis and the various characterization techniques are combined, a picture of the effect of additives on the liquid products derived from the devolatilization of typical South African coals can be formed. An increase in additive load leads to a reduction in tar yields. The quality of the liquid products formed is also affected by an increase in additive load, with the resultant tars having a lighter average weight, a lower average boiling point, and significantly different compositions.

A study of this nature presents a significant insight into the devolatilization behaviour of typical South African coals, and could serve as precursor for the development of a technology capable of producing high-value chemicals, as well as char gasification to produce synthesis gas. The findings demonstrated in this study are in agreement with studies showing that vitrinite-rich coals generally produce tars with a higher amount of aromatic hydrogen and a higher quantity of condensed aromatic systems.

In conclusion, this study showed that the additives acted primarily as catalysts to promote tar cracking during pyrolysis. The quality of the tars produced in this manner should be quantified in further studies using gas chromatography/mass spectrometry to identify chemical families present (boiling point $<300^{\circ} \mathrm{C}$ ), i.e. alkyl benzenes, phenols, cresol and paracresol, furans, alkanes, polycyclic aromatic compounds (PAH), and long-chain alcohols. In addition, since it is known that char reactivity is significantly enhanced by alkali metal catalysts, further work should be conducted to assess the reactivity of the catalysed char. The authors believe that this would establish a more direct link between the numerous results obtained and a potential new value-add to coal technology will be realized.

\section{Acknowledgement}

The work presented in this paper is based on research financially supported by the South African Research Chairs Initiative of the Department of Science and Technology and National Research Foundation of South Africa (Coal Research Chair Grant No. 86880, UID85643, UID85632). Any opinion, finding, or conclusion or recommendation expressed in this material is that of the authors and the NRF does not accept any liability in this regard.

\section{References}

Ahmad, T., Awan, I.A., NisAr, J., and Ahmad, I. 2009. Influence of inherent minerals and pyrolysis temperature on the yield of pyrolysates of some Pakistani coals. Energy Conversion and Management, vol. 50. pp. 1163-1171.

AnTAL, M.J. and VÁRHEGYI, G. 1995. Cellulose pyrolysis kinetics: the current state of knowledge. Industrial \& Engineering Chemistry Research, vol. 34. pp. 703-717.

Bell, D.A., Towler, B.F., and FAn, M. 2011. The nature of coal. Coal Gasification and Its Applications. Elsevier, Amsterdam. Chapter 1. pp. $1-15$.

BeuKMan, M.T. 2009. Coal pyrolysis modelling and the influence of pyrolysis conditions of char reactivity for large particles. MEng dissertation, University of Potchefstroom, South Africa.

ChEn, L. And Wen, C.Y. 1979. A model for coal pyrolysis. American Chemical Society Division of Fuel Chemistry Preparation, vol. 24. pp. 141-152.
Cypres, R. and Soudan-Moinet, C. 1980. Pyrolysis of coal and iron oxides mixtures. 1. Influence of iron oxides in the pyrolysis of coal. Fuel, vol. 59. pp. 48-54.

DAYTON, D. 2002. A review of the literature on catalytic biomass tar destruction. NREL/TP-510-32815. National Renewable Energy Laboratory, Golden, CO. pp. 1-28.

European Chemicals Agency (ECHA). 2009. Proposal for identification of a substance as a CMR, PBT, vPvB or a substance of an equivalent level of concern. Helsinki, Finland.

Fletcher, T.H., Kerstein, A.R., PugmiRe, R.J., and Grant, D.M. 1992. Chemical percolation model for devolatilization. 3. Direct use of C13 NMR data to predict effects of coal type. Energy \& Fuels, vol. 6. pp. 414-431.

Franklin, H., Peters, W., Carlello, F., and Howard, J. 1981. Effects of calcium minerals on the rapid pyrolysis of a bituminous coal. Fuel, vol. 20. pp. 670-674.

Franklin, H., Cosway, R., Peters, W., and Howard, J. 1983. Effects of cations on the rapid pyrolysis of a Wyodak subbituminous coal. Fuel, vol. 22. pp. 39-42.

Fuchs, W. and Sandhoff, A.G. 1942. Theory of coal pyrolysis. Industrial and Engineering Chemistry, vol. 34. pp. 567-571.

Hashimoto, K., MiURA, K., and UEDA, T. 1986. Correlation of gasification rates of various coals measured by a rapid heating method in a steam atmosphere at relatively low temperatures. Fuel, vol. 65. pp. 151-61523.

Hayashi, J., Takahasi, H., Doi, S., Kumagai, H., Chibe, T., Yoshida, T., and TsuTsumi, A. 2000. Reactions in brown coal pyrolysis responsible for heating rate effect on tar yield. Energy \& Fuels, vol. 14. pp. 400-408.

HowARD, J.B. 1981. Chemistry of Coal Utilization. Wiley, New York. 1150 pp.

Hu, H., Zhou, O., Zhu, S., Meyer, B., Krzack, S., and Chen, G. 2004. Product distribution and sulphur behaviour in coal pyrolysis. Fuel Processing Technology, vol. 85. pp. 849-861.

Haykiri-Acma, H., Yaman, S., and KuсUKAYRAK, S. 2012. Effect of pyrolysis temperature on burning reactivity of lignite char. Energy Education Science and Technology Part A: Energy Science and Research, vol. 29. pp. 1203-1216.

Iglesias, M.J., Cuesta, M.J., and Ruiz, I.S. 2001. Structure of tars derived from low-temperature pyrolysis of pure vitrinites: Influence of rank and composition of vitrinites. Journal of Analytical and Applied Pyrolysis, vol. 58. pp. 255-284.

JENKINS, R.G., NANDI, S., and WALKER, J.R.' 1973. Reactivity of heat-treated coals in air at $500^{\circ} \mathrm{C}$. Fuel, vol. 52. pp. 288-293.

Juntgen, H. and van HEecK, K.H. 1977. Research in the field of pyrolyses at Bergbau-Forschung during the last fifteen years. Proceedings of the Meeting on Coal Fundamentals, Stoke Orchard, UK.

Kandiyoti, R., Herod, A., and BartLe, K. 2006. Solid Fuels and Heavy Hydrocarbon Liquids. Thermal Characterisation and Analysis. Elsevier, Amsterdam.

KRISTIANSEN, A. 1996. Understanding coal gasification. IEA Coal Research, London. $70 \mathrm{pp}$.

Kyotani, T., Kubota, K., CaO, J., Yamashita, H., and Tomia, A. 1993. Combustion and $\mathrm{CO}_{2}$ gasification of coals in a wide temperature range. Fuel Processing Technology, vol. 36. pp. 209-217.

LADNER, W.R. 1988. The products of coal pyrolysis: properties, conversion and reactivity. Fuel Processing Technology, vol. 20. pp. 207-222.

Liu, Q., Hu, H., ZHou, Q., ZHu, S., and CHEN, G. 2004. Effect of inorganic matter on reactivity and kinetics of coal pyrolysis. Fuel, vol. 83. pp. 713-718.

Morgan, T.J., George, A., and Davis, D.B. 2008. Optimization of $1 \mathrm{H}$ and $13 \mathrm{C}$ NMR methods for structural characterization of acetone and pyridine soluble/insoluble fractions of a coal tar pitch. Energy \& Fuels, vol. 22. pp. 1824-1835.

Mori, T., Амамото, S., Kusakabe, K., and Morooka, S. 1996. Flash pyrolysis of brown coal modified by alcohol-vapor explosion treatment. Energy \& Fuels, vol. 10. pp.1099-1107.

MiURA, K., HASHimoto, K., and Silveston, P.L. 1989. Factors affecting the reactivity of coal chars during gasification, and indices representing reactivity. Fuel, vol. 68. pp. 1461-1475.

Muhlen, H.J., Sowa, F., and van HeEK, K.H. 1993. Comparison of the gasification behaviour of a West and East German brown coal. Fuel Processing Technology, vol. 36. pp. 185-191.

Nelson, P.F., Smith, I.W., Tyler, R.J., and MAckie, J.C. 1988. Pyrolysis of coal at high temperatures. Energy \& Fuels, vol. 2. pp. 391-400.

Nishiyama, Y. 1991. Catalytic gasification of coals - Features and possibilities. Fuel Processing Technology, vol. 29. pp. 31-42

ÖzTAS, N.A. and Yurum, Y. 2000. Pyrolysis of Turkish Zonguldak bituminous coal. Part 1. Effect of mineral matter. Fuel, vol. 79. pp. 1221-1227. 


\section{Influence of additives on the devolatilization product yield of typical South African coals}

Pan, X., Du, K., Wang, S., and Zhang, D. 2011. Characterization of lowtemperature coal tars derived from pyrolysis of coals exploited in different depositional environments. Petrochemical Technology, vol. 40. pp. 785-789.

Peters, W. and Bertuing, H. 1965. Kinetics of the rapid degasification of coals. Fuel, vol. 44. pp. 317-331.

PinHeiro, H.J. 2010. A techno-economic and historical review of the South African coal industry in the 19th and 20th centuries and analyses of coal product samples of South African collieries 1998-1999. Bulletin 113. Department of Minerals and Energy, Pretoria, South Africa.

Pusz, S., Krzton, A., Komraus, J.L., Martinez-Tarazona, M.R., MartinezALonso, A., and TAscon, J.M.D. 1997. Interactions between organic matter and minerals in two bituminous coals of different rank. Coal Geology, vol. 33. pp. 369-386.

Rennhack, R. 1964. The kinetics of devolatilization of coke. Brennstoff-Chemie, vol. 45. p. 300.

RaveEndRan, K., Ganesh, A., and KhILAR, K.C. 1995. Influence of mineral matter on biomass pyrolysis characteristics. Fuel, vol. 74, no. 5. pp. 631-653.

RaveEndran, K., Ganesh, A., and KhILAR, K.C. 1996. Pyrolysis characteristics of biomass and biomass components. Fuel, vol. 75, no. 8. pp. 987-998.

RICHARDS, G.N. and ZHENG, G. 1991. Influence of metal ions and of salts on products from pyrolysis of wood: applications to thermochemical processing of newsprint and biomass. Journal of Analytical and Applied Pyrolysis, vol. 21. pp. 133-146.

Roets, L., Bunt, J.R., Neomagus, H.W.J.P., and van NieKERK, D. 2014. An evaluation of a new automated duplicate-sample Fischer Assay setup according to ISO/ASTM standard and analysis of the tar fraction. Journal of Analytical and Applied Pyrolysis, vol. 106. pp. 190-196.

Samaras, P., Diamadopoulos, E., and SaKellaropoulos, G.P. 1996. The effect of mineral matter and pyrolysis conditions on the gasification of Greek lignite by carbon dioxide. Fuel, vol. 75. pp. 1108-1114.

SANS (South African National Standards). 1974. Brown coals and lignintes, Determination of the yields of tar, water, gas and coke residue by low temperature distillation. SANS 647. SABS, Standards Division, Pretoria.

Schobert, H.H. and Song, C. 2002. Chemicals and materials from coal in the 21st century. Fuel, vol. 81. pp. 15-32.

ScHobert, H.H. and Song, C. 1995. Non-fuel uses of coals and synthesis of chemicals and materials. Fuel, vol. 75. pp. 724-736.
Shadle, L., Berry, D., and Syamlal, M. 2002. Coal gasification. Kirk-Othmer Encyclopedia of Chemical Technology.

SLAGHUIS, J.H., FERREIRA, L.C., and JUdD, M.R. 1991. Volatile matter in coal: effect of inherent mineral matter. Fuel, vol. 70. pp. 471-473.

Smith, K.L., Smoot, J.D., Fletcher, T.H., and Pugmire, R.J. 1994. The Structure and Reaction Processes of Coal. Plenium Press, New York.

Solomon, P.R. and Hamblen, D.G. 1985. Pyrolysis. Chemistry of Coal Conversion. Plenum Press, New York. Chapter 5. pp. 121-251.

Song, C. and Moffat, K. 1994. Zeolite-catalysed ring-shift isomerisation of symoctahydrophenanthrene and conformational isomerisation of symdecahydronaphthalene. Microporous Materials, vol. 2. pp. 459-466.

SonG, C. and ScHoBert, H.H. 1993. Opportunities for developing speciality chemicals and advanced materials from coal. Fuel Processing Technology, vol. 34. pp. 157-196.

Speight, J.G. 1994. The Chemistry and Technology of Coal. Marcel Dekker, New York.

Uкwuома, 0. 2002. Comparative study of the compositional characteristics of liquids derived by hydrotreating of Nigerian tar sand bitumen. Petroleum Science and Technology, vol. 20. pp. 525-534.

VReugdenhiL, B.J. and ZwART, R.W.R. 2009. Tar formation in pyrolysis and gasification. ECN-E--08-087. ECN - Energy Center at the Netherlands. pp. 1-37.

WANZL, W. 1988. Chemical reactions in thermal decomposition of coal. Fuel Processing Technology, vol. 20. pp. 317-366.

WORLD COAL InSTITUTE (WCI). 2008. Coal facts. London.

Wornat, M.J. and NeLSON, P.J. 1992. Effects of ion-exchanged calcium on brown coal tar composition as determined by Fourier transform infrared spectroscopy. Energy \& Fuels, vol. 6. pp. 136-142.

Wu, Z., Sugimoto, Y., and Kawashima, H. 2003. Effect of demineralization and catalyst addition on $\mathrm{N}_{2}$ formation during coal pyrolysis and on char gasification. Fuel, vol. 82. pp. 2057-2064.

Yaw, D., Longwell, J.P., Howard, J.B., And Peters, W.A. 1980. Effect of calcined dolomite on the fluidized bed pyrolysis of coal. Industrial and Engineering Chemical Process Design and Development, vol. 19. pp. 645-653.

YE., D.P., Agnew, J.B., and ZHANG, D.K. 1998. Gasification of a South Australian low-rank coal with carbon dioxide and steam: kinetics and reactivity studies. Fuel, vol. 77. pp. 1209-1219. 